\title{
Chapter 8 \\ Possibilities for the Establishment of an \\ MIC and a Possible Connection to Existing \\ Institutions and System Conformity
}

In light of the statements above and the very specific requirements that should be put

on the MIC, acceptance of MIC judgments as arbitral awards in the meaning of the New York Convention in states where enforcement is sought, seems questionable. It follows that the best option for an effective MIC would be to establish it as an independent multilateral court, which should provide for its own procedural rules as well as enforcement provisions or even an own independent fund system. ${ }^{1}$

This would not only ensure a largely consistent application of the investment standards, but also an effective enforcement of MIC judgments. Such a multilateral court should be open for accession to other states and Regional Economic Integration Organisations (REIOs).

\subsection{Practical Implementation of the Establishment of an MIC}

The establishment of an international dispute settlement institution is usually accomplished by means of a treaty or other international agreement. For that, there are different basic models available.

Dispute resolution institutions are often designed as organs of international organisations, as independent international organisations themselves or also as mere bodies for the implementation or application of the treaty. ${ }^{2}$ In this way, the

${ }^{1}$ For a similar recommendation see European Union (2019), para. 31.

${ }^{2}$ Giorgetti (2016), p. 890. 
ICJ is a main organ of the $\mathrm{UN},{ }^{3}$ the CJEU is an EU institution ${ }^{4}$ and both the International Criminal Tribunal for the former Yugoslavia (ICTY) and Rwanda (ICTR) are subsidiary organs of the United Nations Security Council. ${ }^{5}$ On the other hand, many international courts, such as the International Criminal Court, are designed as separate international organisations. ${ }^{6}$ In addition, some international treaties foresee the establishment of dispute settlement mechanisms that are either established as permanent courts (ITLOS for the UN Convention on the Law of the Sea, ${ }^{7}$ ECtHR for the ECHR ${ }^{8}$ ) or mere bodies for the application of the treaty (such as the Human Rights Committee under the International Covenant on Civil and Political Rights (ICCPR)). ${ }^{9}$

545 In the field of investment dispute resolution, two institutions, although they do not exercise any dispute resolution function, but rather mere administrative bodies supporting activities for arbitral tribunals, are considered to be international organisations. This is clearly the case with ICSID, which was established by the Washington Convention of 1965 as an international organisation with explicit international legal personality. ${ }^{10}$ The PCA is also an international organisation,

\footnotetext{
${ }^{3}$ Article 7 para. 1 UN Charter: "There are established as principal organs of the United Nations: a General Assembly, a Security Council, an Economic and Social Council, a Trusteeship Council, an International Court of Justice and a Secretariat." Article 1 ICJ Statute: "The International Court of Justice established by the Charter of the United Nations as the principal judicial organ of the United Nations shall be constituted and shall function in accordance with the provisions of the present Statute."

${ }^{4}$ Article 13 para. 1 TEU: “[...] The Union's institutions shall be: the European Parliament, the European Council, the Council, the European Commission (hereinafter referred to as "the Commission"), the Court of Justice of the European Union, the European Central Bank, the Court of Auditors."

${ }^{5}$ Giorgetti (2016), p. 892.

${ }^{6}$ Article 4 para. 1 ICC Statute: "The Court shall have international legal personality. It shall also have such legal capacity as may be necessary for the exercise of its functions and the fulfilment of its purposes." Schabas (2010), p. 94.

${ }^{7}$ United Nations Convention on the Law of the Sea, 10 December 1982, UN Doc A/CONF 62/122 (1982), www.un.org/Depts/los/convention_agreements/texts/unclos/unclos_e.pdf; Boisson de Chazournes (2012), p. 111.

${ }^{8}$ Article 19 Protocol No. 11 to the Convention for the Protection of Human Rights and Fundamental Freedoms, restructuring the Control Machinery established thereby: "To ensure the observance of the engagements undertaken by the High Contracting Parties in the Convention and the protocols thereto, there shall be set up a European Court of Human Rights, hereinafter referred to as the Court. It shall function on a permanent basis."

${ }^{9}$ Amerasinghe (1996), pp. 160 et seq.

${ }^{10}$ Article 18 ICSID Convention: "The Centre shall have full international legal personality." Schreuer et al. (2009), p. 59: "Despite close legal ties between the Centre and the World Bank, the Centre is an autonomous international organization, enjoying its own international legal personality."
} 
founded by the Hague Convention in $1899 .{ }^{11}$ Both international organisations are based on treaties, have states as members and are open to further parties.

For the establishment of the MIC, the creation of an independent international organisation by means of an international treaty (MIC Statute) would be the most appropriate option (see paras. 548 et seqq.). ${ }^{12}$ The creation of an international organisation would ensure the essential points for the functioning of an independent court, such as functional immunity for the judges, equal financial treatment for the parties to the agreement, the conclusion of seat and immunity agreements etc.

\subsection{Structuring the MIC as an International Organisation}

The legal situation of the MIC would be determined in the national legal arena by privileges and immunities. Immunity guarantees would secure its functionality. As an international organisation, the MIC would enjoy legal personality under international and national law. This would ensure that the MIC could conclude international treaties such as a seat agreement establishing the necessary privileges and immunities. At the same time, it could conclude contracts under national law, acquire assets and rent facilities etc. The latter aspect of a legal personality under national law is usually achieved by provisions, according to which an international organisation explicitly has the right to conclude private law contracts, to acquire assets and to initiate proceedings before state courts. ${ }^{13}$ In numerous recent treaties that establish international organisations, international legal personality is also expressly foreseen. ${ }^{14}$ The MIC should also follow this example.

Central to the effective implementation of judicial independence would be a functional immunity from jurisdiction for the judges as seen in all international courts and quasi-judicial dispute resolution organs. ${ }^{15}$ At the same time, the MIC, to

\footnotetext{
${ }^{11} 1899$ Convention for the Pacific Settlement of International Disputes, 29 July 1899, https://pcacpa.org/wp-content/uploads/sites/175/2016/01/1899-Convention-for-the-Pacific-Settlement-ofInternational-Disputes.pdf; Daly (2012), p. 38.

${ }^{12}$ For a similar reference by the European Union which presumes the use of an instrument to establish the standing mechanism (the term used for the new investment court), see European Union (2019), paras. 27, 31, 35.

${ }^{13} \mathrm{Cf}$. Article 18 sentence 2 ICSID Convention: "The legal capacity of the Centre shall include the capacity: (a) to contract; (b) to acquire and dispose of movable and immovable property; (c) to institute legal proceedings."

${ }^{14} \mathrm{Cf}$. Article 18 sentence 1 ICSID Convention; Article VIII: 1 WTO Agreement; Article 47 TEU; Article 4 ICC Statute.

${ }^{15} \mathrm{Cf}$. Article 21 ICSID Convention: "The Chairman, the members of the Administrative Council, persons acting as conciliators or arbitrators or members of a Committee appointed pursuant to paragraph (3) of Article 52, and the officers and employees of the Secretariat (a) shall enjoy immunity from legal process with respect to acts performed by them in the exercise of their functions, except when the Centre waives this immunity; [...]." Article VIII WTO Agreement: "(3) The officials of the WTO and the representatives of the Members shall similarly be accorded by
} 
whom decisions could be attributed to, should enjoy immunity from national court jurisdiction, ${ }^{16}$ in order to avoid any interference with the independence of the MIC in its decision-making process through complaints before national courts.

Furthermore, it would be important to grant the other usual privileges and immunities to the MIC as well as the judges and other staff of the organisation. These include the right of free movement and residence, customs relief, exemptions from social security contributions etc. ${ }^{17}$

550 These also include tax exemptions, which should not be misunderstood as personal privileges of the judges and other staff of the MIC, but rather reflect the principle of equal treatment of MIC Member States. ${ }^{18}$ Only an exemption from income taxation by the host state would ensure that the salaries of the judges and other staff of the MIC funded by the Member States would not disproportionally benefit the host state.

551 These privileges and immunities could already be stated in the basic treaty, in a separate privileges and immunities protocol or in a seat agreement. The United Nations Convention on Privileges and Immunities serves as a model for many other immunity agreements. ${ }^{19}$ In particular, with regard to safeguarding judicial immunity, it would make sense to provide for this in a multilateral instrument (and not a mere bilateral seat agreement).

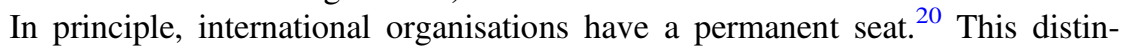
guishes them, inter alia, from arbitral tribunals. The seat of the MIC should be at the place where the Secretariat works and the Plenary Body meets. ${ }^{21}$ In any case, in

each of its Members such privileges and immunities as are necessary for the independent exercise of their functions in connection with the WTO. (4) The privileges and immunities to be accorded by a Member to the WTO, its officials, and the representatives of its Members shall be similar to the privileges and immunities stipulated in the Convention on the Privileges and Immunities of the Specialized Agencies, approved by the General Assembly of the United Nations on 21 November 1947." Article 19 ICJ Statute: "The members of the Court, when engaged on the business of the Court, shall enjoy diplomatic privileges and immunities." Article 51 ECHR: "The judges shall be entitled, during the exercise of their functions, to the privileges and immunities provided for in Article 40 of the Statute of the Council of Europe and in the agreements made thereunder."

${ }^{16} \mathrm{Cf}$. Article 20 ICSID Convention "The Centre, its property and assets shall enjoy immunity from all legal process, except when the Centre waives this immunity."

${ }^{17}$ See in this respect the detailed explanations of Reinisch (2016a).

${ }^{18}$ Kunz (1947), pp. 860 et seq.; Martha (2016), pp. 219 et seqq. An exemption from taxes was also proposed for the judges of the Arab Investment Court under Art. 28(4) of the Unified Agreement for the Investment of Arab Capital in the Arab States, 1980.

${ }^{19}$ Ruffert and Walter (2015), para. 184; Reinisch (2016b), pp. 1048-1068.

${ }^{20}$ Article 3 para. 1 ICC Statute: "The seat of the Court shall be established at The Hague in the Netherlands ('the host State')." Article 22 para. 1 ICJ Statute: "The seat of the Court shall be established at The Hague. This, however, shall not prevent the Court from sitting and exercising its functions elsewhere whenever the Court considers it desirable." Article 28 para. 5 Arab Investment Court Agreement: "The seat of the Court shall be at the permanent headquarters of the League of Arab States and shall not be transferred unless the Court takes a substantiated decision to convene its sessions or undertake its functions in another location."

${ }^{21}$ Ruffert and Walter (2015), para. 189. 
the interest of better international acceptance of the MIC, the option of providing for several seats could also be considered. If necessary, organs of the MIC could be connected to the existing infrastructure of other international organisations and courts (see para. 560 et seqq.). A seat for the Plenary Body could be located in Geneva, as the representatives of the Members of the General Council of the WTO, which are likely to be identical with the representatives of the Members of the MIC Plenary Body, are already present there. In addition, it should be discussed whether, with a large number of member states from all continents, several locations for the conducting of negotiations on all continents should be considered.

The relationship of the MIC with the host state should be regulated in a seat agreement, in which the balance between the MIC's interest in effective work as well as the economic and security concerns of the host state can be found. ${ }^{22}$ The MIC Statute, which could already incorporate immunity rules, should therefore be supplemented with further seat and immunity agreements concluded with, inter alia, the host state of the MIC. These contain rules on:

- the protection of the facilities of the MIC; protection of the MIC staff, including their immunity;

- a guarantee of the free movement of persons of judges and other staff;

- dispute settlement in connection with the seat agreement; and

- questions of tax exemption.

It would also be possible to conclude a main seat agreement and to regulate the details regarding e.g. the meetings of the Plenary Body, or to regulate the establishment of the negotiation venues in an open or undefined way so that further concretization of it is possible through secondary law.

Furthermore, it could also be determined with regard to the seat that for instance the President of the Court must also live at the seat of the MIC. ${ }^{23}$

\subsection{Connection to Existing Institutions}

The model examined here of a two-tiered MIC is in principle difficult to integrate into the structure of existing models. In addition to the establishment of an independent international organisation, the connection to existing institutions would also come into question.

In the CETA/TTIP discussion on the establishment of bilateral permanent judicial institutions to settle investment disputes, a preference for the integration in the ICSID system is shown. This is reflected, in particular, in the idea that the decisions of the planned "courts" can be considered as ICSID arbitral awards. However, as has

\footnotetext{
${ }^{22}$ Ruffert and Walter (2015), para. 193.

${ }^{23}$ Cf. e.g. Article 22 para. 2 ICJ Statute: "The President and the Registrar shall reside at the seat of the Court."
} 
already been pointed out (see para. 498), even if such an inter se modification of the ICSID Convention would be allowed, such modified arbitral awards would only be seen as ICSID awards by the modifying parties. Therefore, the essential advantage of the ICSID Convention, namely automatic enforceability in all member states, would be lost. The parties to the ICSID Convention that do not participate in the modification are not obliged to enforce such modified arbitral awards from a CETA or TTIP court. Therefore, a direct institutional connection between the MIC and ICSID does not seem practical. Moreover, an amendment of the ICSID Convention that requires unanimity seems rather unrealistic, ${ }^{24}$ especially because some states that explicitly oppose the MIC System are unlikely to agree on an amendment of the ICSID Convention. $^{25}$

558 It has also been suggested that an investment court should be integrated into the WTO Dispute Settlement System. However, this would require a fundamental change of the DSU. The WTO Dispute Settlement System is open to its members only, never to private persons, i.e. investors. ${ }^{26}$ In addition, in the past, a substantive extension of WTO Law to allow access and protection of foreign investments has repeatedly failed, as it happened during the Uruguay Round ${ }^{27}$ with one of the so-called Singapore Issues. ${ }^{28}$ An integration into the WTO System thus also appears to be unrealistic at the present time. ${ }^{29}$

559 The same applies to a connection of the MIC with the ICJ because, in addition to an extensive change of jurisdiction of the ICJ, access to the Court would have to be made possible for natural and legal persons, i.e. the ICJ Statute would have to be extensively amended. ${ }^{30}$

560 This does not preclude, however, making use of the institutional expertise of ICSID and its facilities etc. That would of course be possible for the MIC as an independent international organisation. So far, the ICSID Secretariat has offered its support in non-ICSID arbitration procedures and has provided administrative support in procedures under UNCITRAL and other arbitration rules. ${ }^{31}$

\footnotetext{
${ }^{24}$ Article 66 para. 1 ICSID Convention: "If the Administrative Council shall so decide by a majority of two-thirds of its members, the proposed amendment shall be circulated to all Contracting States for ratification, acceptance or approval. Each amendment shall enter into force 30 days after dispatch by the depositary of this Convention of a notification to Contracting States that all Contracting States have ratified, accepted or approved the amendment."

${ }^{25}$ American Bar Association Section on International Law (2016), p. 120.

${ }^{26}$ Cf. Article 1.1 DSU: "[...] the settlement of disputes between Members [...]." A change therefore would only be possible according to Art. X of the WTO Agreement.

${ }^{27}$ Herrmann et al. (2007), para. 790.

${ }^{28}$ Compare-decision of the General Council regarding the work program of the Doha agenda of 1.8.2004 (July package), WT/L/579.

${ }^{29}$ See in this respect as well American Bar Association Section on International Law (2016), p. 129.

${ }^{30}$ American Bar Association Section on International Law (2016), p. 120.

${ }^{31}$ The Secretariat of the ICSID has been designated as the Secretariat for the Investment Tribunal and the Appeal Tribunal under Art. 3.09(16) and 3.10(14) EU-Singapore IPA (draft for signature), Art. 3.38(18) and 3.39(18) EU-Vietnam IPA (draft for signature) and Art. 11(17) and Art. 12
} 
Similarly, in an agreement between the MIC and ICSID or also the PCA or other arbitral institutions, logistical and staff support could be obtained. The MIC could therefore share infrastructure with other organisations that do not fully use their infrastructure either at an initial phase of the MIC or even in the long term. ${ }^{32}$ In particular, during an initial phase when the amount of cases is not yet foreseeable, it could be beneficial to use hearing facilities and secretarial support from such existing institutions, to avoid setting up expensive court infrastructure. After the initial phase, the average number of procedures could be more easily estimated and the judicial bench could potentially be expanded (see paras. 111 et seqq.). During an expansion phase, the court could acquire its own premises once the longer-term sharing of infrastructure with other institutions or organisations no longer seems possible.

Here, in addition to ICSID in Washington, the ITLOS in Hamburg or the PCA with its various locations could be considered. ${ }^{33}$ It would certainly also be necessary to decide whether to have the seat of the MIC in a state that is unlikely to show any interest in membership in the near future. In any case, as far as infrastructure is concerned, a considerable amount of money could be saved or infrastructure of other organisations and institutions could be used more effectively. The money saved in

(15) EU-Mexico Global Agreement (draft for signature) as on February, 2019; The ICSID Secretariat has also been recommended as an option by Katz (2016), p. 180; See also ICSID website, Case Administration for Non-ICSID cases, https://icsid.worldbank.org/en/Pages/Process/NonICSID-Arbitration.aspx: "In addition to administering proceedings under the ICSID rules, the Centre is also available to administer arbitration cases under other rules, such as the UNCITRAL Arbitration Rules and ad hoc investor-State and State-State cases. These non-ICSID cases are submitted to ICSID by agreement of the parties either prior to the constitution of the Tribunal or once the Tribunal is constituted. On occasion, the Secretary-General of ICSID also serves as appointing authority of an arbitrator. The services rendered by the Centre in non-ICSID cases may range from limited assistance with the organization of hearings and management of the case finances to full secretariat services in the administration of the case concerned. Parties and Tribunals are free to elect the extent of the services desired." For further discussion on the use of the ICSID Secretariat to support an Investment Court System, See, European Commission (2017), p. 36.

${ }^{32}$ For a similar suggestion, See, European Commission (2017), p. 49.

${ }^{33} \mathrm{Cf}$. www.nienstedten.de/Burgerverein/Seegericht/body_seegericht.html: "The building [...] had been constructed in the years 1997 to 2000 [...]. The construction costs amounted to 123 million DM ( $80 \%$ were covered by the Federal Republic of Germany, $20 \%$ by the City of Hamburg, the operating costs are covered by the United Nations). [...] The main building consists of 3 courtrooms, 25 offices for judges, 11 conference rooms, and 74 office rooms. Additionally lobby, library, study, catalogue room, storage room, a flat for the facility manager and a grand entrance hall. All rooms are electronically surveilled; the security department is staffed at all times. The used parts of the building cover $4755 \mathrm{~m}^{2}$. In the center of the building in between the two main wings, the main round hall for court session is located, including a bench for the 21 judges. There are two minor halls, which can be connected with the main hall, so that a number of 240 persons in total can be seated. The latest technology, being able to include amendments, without any constructional changes, including four cameras and a media wall. Sound and image can be transported outside of the main hall. A room for video conferences allows hearings of witnesses from remote locations. Translation booths allow simultaneous translations in the six work languages of the UN, if necessary also other languages. A large conference room for the judges is also considered a "safe room" in case of crises. Besides there are two smaller conference rooms and rooms for the parties to the disputes and witnesses and a communications center." 
this way could be invested in first-class staffing: full-time judges, a Secretariat and an Advisory Centre.

563 It has also been proposed ${ }^{34}$ that the project of judicial multilateralisation of an investment dispute settlement system should be promoted with support of UNCITRAL, ${ }^{35}$ OECD and UNCTAD ${ }^{36}$ since these organisations are very interested in reforming ISDS and are already active in the area of ISDS investment protection. As mentioned above and is well known UNCITRAL mandated its Working Group III in 2017 to discuss a reform of investment arbitration. Working Group III is now working on relevant solutions to be recommended to the UNCITRAL Commission. ${ }^{37}$ Especially a structural reform with an MIC is now "on the table". UNCTAD could bring development perspectives into the discussion. ${ }^{38}$ In addition, the ILC could be involved in the work. Likewise, cooperation of the proposed MIC Advisory Center, particularly with the UNCTAD could be considered.

\subsection{Entry into Force of the MIC Statute Only with a Minimum Number of Members}

564 Like with the International Criminal Court, for instance, it might make sense that the MIC Statute only enters into force after a certain number of ratifications. ${ }^{39}$ If only a small number of states are on board for the MIC project, just another ISDS system would emerge alongside the existing ones. Therefore, it should be determined that a certain number of states must ratify an MIC Statute before it can enter into force.

A minimum number of 40 members should be foreseen. In addition to the EU and its 28 Member States, eleven more states would have to be convinced of joining the MIC. The EU is already negotiating or is about to start negotiations for a large number of agreements, all of which should also include investment protection (China, Myanmar, Japan, Mexico, Indonesia, the Philippines). ${ }^{40}$ The agreements

\footnotetext{
${ }^{34}$ American Bar Association Section on International Law (2016), pp. 120 et seq.

${ }^{35}$ See especially UNCITRAL (2017).

${ }^{36}$ See reference to work by UNCTAD in UNCITRAL (2018), paras. 23 et seqq.

${ }^{37}$ See UNCITRAL (2019).

${ }^{38}$ American Bar Association Section on International Law (2016), p. 121.

${ }^{39}$ Cf. e.g. Article 126 para. 1 Rome Statute: "This Statute shall enter into force on the first day of the month after the 60th day following the date of the deposit of the 60th instrument of ratification, acceptance, approval or accession with the Secretary-General of the United Nations."

${ }^{40} \mathrm{See}$ in this respect Overview of FTA and other Trade Negotiations, http://trade.ec.europa.eu/ doclib/docs/2006/december/tradoc_118238.pdf; European Commission (2015), pp. 32 et seqq.
} 
with Vietnam, Mexico, Canada and Singapore have already included a commitment to a multilateral approach. ${ }^{41}$

In the future, therefore, the EU should, in its negotiations of trade, general economic and association agreements, urge its partners to actively participate in the establishment of the MIC and thus strive for their membership thereto. In particular, investment chapters in such agreements or pure investment agreements could provide for (exclusive) jurisdiction of the MIC where appropriate and motivate the respective party to the agreement to join the MIC.

At the same time, the EU can invite its Member States and, as at least parts of the IIAs of the Member States concern exclusive Union competences, also authorise them $^{42}$ to agree on the MIC in new negotiations or renegotiations of their investment agreements as the court having jurisdiction over future disputes. ${ }^{43}$ Here, the Commission's Impact Assessment Study has already indicated that, if the MIC would have jurisdiction for all EU and EU Member States agreements, already half of the existing international investment agreements worldwide would be covered. ${ }^{44}$

\subsection{Establishment of MIC Jurisdiction by Explicit Modification of Existing and Future IIAs}

The considerations above are based on the assumption that the existing IIAs will remain largely in force, i.e. existing IIAs will be modernised and Member State agreements will gradually be replaced with EU agreements. It should therefore be shown how this particular substantive network could be linked to a two-tiered MIC at dispute resolution level. To clarify once more: the substantive protection standards would not be found in the MIC Statute, but would in principle continue to be present in other international treaties and obligations. The immediate use of the existing IIA-network has the advantage that in the case of existing agreements, no negotiations on protection standards need to take place.

\footnotetext{
${ }^{41}$ Art. 3.41, EU-Vietnam IPA (draft for signature) as on 2 April, 2019; Art. 14, Section - Resolution of Investment Disputes, EU-Mexico Global Agreement (draft for signature) as on 2 April, 2019; Art. 8.29, Comprehensive Economic and Trade Agreement, OJ L 11, 14.1.2017, p. 23; Art. 3.12, EU-Singapore IPA (draft for signature) as on 2 April, 2019.

${ }^{42} \mathrm{Cf}$. Article 2 para. 1 TFEU: "When the Treaties confer on the Union exclusive competence in a specific area, only the Union may legislate and adopt legally binding acts, the Member States being able to do so themselves only if so empowered by the Union or for the implementation of Union acts."

${ }^{43}$ The Netherlands has already included a reference to the Multilateral Investment Court in Art. 15 of its Draft BIT, 2018.

${ }^{44}$ European Commission (2016a, b).
} 


\subsubsection{Conclusion of New IIAs and FTAs with Investment Chapters}

569 Firstly, the establishment of MIC jurisdiction should take place through express determination of its jurisdiction in new agreements of the EU and of other states who wish to promote this new system. The EU negotiates free trade and/or investment protection agreements or prepares negotiations with a large number of states. ${ }^{45}$ First of all, it should be determined in the MIC Statute that, in the future, all newly concluded agreements of the MIC Members in the area of investment protection should foresee the exclusive possibility of dispute resolution by the MIC. As a result, in their international treaty negotiations, all Members should endeavour to promote the extension of the MIC membership in the future (by way of a memorandum of understanding).

570 In this context, it could be explicitly stated in future agreements concluded by the EU that, after its establishment, the MIC alone has jurisdiction to settle claims of investors. ${ }^{46}$ In addition, the investment court system foreseen in the previous agreements could automatically lose its jurisdiction or its jurisdiction could pass on to the MIC as soon as it has been established. Transitional provisions should also be foreseen, as it is likely that the EU will negotiate further agreements, until the MIC is established and operational.

571 In addition, the agreements should stipulate that the parties to the agreement would actively participate in the negotiations on the establishment of a MIC and become members too. Furthermore, in new EU free trade and/or investment protection agreements, it should be provided for that in the future both parties to the agreement would actively participate in the promotion of a multilateral investment protection system and thus make the MIC the subject of negotiations with third countries ("snowball system").

\footnotetext{
${ }^{45}$ See in this respect recently European Commission (2015), pp. 32 et seqq.

${ }^{46}$ For a subsequent discussion on the need to promote the ability of the MIC to deal with disputes based on existing and future agreements, See, European Union (2019), para. 35.
} 


\subsubsection{Renegotiation and Reform of Existing EU Economic Agreements}

Secondly, existing trade agreements of the EU (association agreements, framework agreements, ${ }^{47}$ pure FTAs, ${ }^{48}$ partnership agreements ${ }^{49}$ ) are constantly reformed and renegotiated. In the event that investment protection is agreed with the respective partners, the respective party to the agreement should be requested to join the MIC. ${ }^{50}$ For example, the agreement with Mexico has now been complemented with an investment protection chapter with reference to a Multilateral Dispute Settlement Mechanism. ${ }^{51}$ This could then also establish the jurisdiction of the MIC for investment protection matters.

\subsubsection{Inclusion of "IIA Networks" of the Member States in the Establishment of MIC Jurisdiction}

Thirdly, in the renegotiations of their BITs, Member States should be obliged by the EU (based on its competence by virtue of Article 207 TFEU) to replace the existing ISDS systems contained therein with a reference to the jurisdiction of the MIC. This could be practical once there are more precise ideas about the design of the MIC, in particular once the requirements for its jurisdiction are determined. It could then come to an instrumentalisation of the IIAs of the Member States; the Member States could each use their bargaining power to reform long-term agreements with their treaty partners and encourage them to include the MIC.

In the future, after the establishment of the MIC, a clause could be included in the modified IIAs of the Member States to the effect that only the MIC (upon its establishment) has jurisdiction to decide investment disputes based on the IIAs of the Member States.

\footnotetext{
${ }^{47}$ Cf. e.g. Framework Agreement on Comprehensive Partnership and Cooperation between the European Union and its Member States, of the one Part, and the Socialist Republic of Viet Nam, of the other Part, OJ L 329 of 3.12.2016, p. 8.

${ }^{48}$ Cf. e.g. Free Trade Agreement between the European Union and its Member States, of the one part, and the Republic of Korea, of the other part, OJ L 127 of 14.5.2011, p. 6.

${ }^{49}$ Cf. e.g. Strategic Partnership Agreement between the European Union and its Member States, of the one part, and Canada, of the other part, OJ L 329 of 3.12.2016, p. 45; Council Decision (EU) 2016/1850 of 21 November 2008 on the signature and provisional application of the stepping stone Economic Partnership Agreement between Ghana, of the one part, and the European Community and its Member States, of the other part, OJ L 287 of 26.10.2016, p. 3.

${ }^{50} \mathrm{~A}$ discussion on insertion of relevant clauses during the process of re-negotiation can be seen in European Commission (2017), pp. 50 et seqq.

${ }^{51}$ Cf. European Commission (2015), pp. 35 and 37. The draft of the EU-Mexico Global Agreement released on 21 April, 2018 contains a reference to a Tribunal along with an obligation on the parties to support the establishment of a Multilateral Dispute Settlement Mechanism.
} 
In addition, it could be provided in the renegotiations that both parties to the respective agreement, if they have not yet done so, commit to join the MIC and, in agreements with other states, advocate for an exclusive establishment of MIC jurisdiction ("snowball system").

576 The aim here could be to link at least part of the approximately 1400 EU Member State IIAs to the MIC dispute settlement system and thus thereby contribute to the gradual increase of MIC membership. ${ }^{52}$

\subsection{The MIC Statute as Opt-In Convention for the Modification of Existing IIAs}

577 As stated above, the MIC should preferably be established as a separate international organisation. This requires the conclusion of an international treaty, the MIC Statute. The MIC Statute could be designed as an opt-in convention. With each accession, the MIC would at least supplement other dispute settlement mechanisms. The text of the existing IIAs between MIC Members would then not have to be modified or renegotiated. The MIC's jurisdiction could be justified by means of an opt-in convention similar to the Mauritius Convention, ${ }^{53}$ whereby States could be obliged by the MIC Statute to offer dispute resolution by the MIC, at least additionally for

\footnotetext{
${ }^{52}$ List of the bilateral investment agreements referred to in Article 4(1) of Regulation (EU) No 1219/ 2012 of the European Parliament and of the Council of 12 December 2012 establishing transitional arrangements for bilateral investment agreements between Member States and third countries OJ C 149 of 27.4.2016, p. 1 according to which the United Kingdom currently has concluded 94 bilateral investment agreements.

${ }^{53}$ United Nations Convention on Transparency in Treaty-Based Investor-State Arbitration (Mauritius Convention on Transparency), signed on 10.12.2014, entered into force on 18.10.2017. The Mauritius Convention allows the application of the new UNCITRAL transparency rules in investor state arbitration proceedings also in cases of IIAs, which have been concluded in the past. The UNCITRAL Rules on Transparency will always apply, for example, in arbitration proceedings to which Germany is one of the parties (after the Mauritius Convention has been ratified by Germany), if the other contracting parties of the respective IIAs did as well ratify the Convention or if the claimant investor suing the Federal Republic of Germany agrees to the application of the Convention. Necessary condition for the application of the transparency rules in investor state arbitration proceedings is either that both parties to the respective IIAs have ratified the Mauritius Convention or that the defending state has ratified the Convention and the investor agreed on the application of the transparency rules. Cf. Article 2 Mauritius Convention: "The UNCITRAL Rules on Transparency shall apply to any investor-State arbitration, whether or not initiated under the UNCITRAL Arbitration Rules, in which the respondent is a Party that has not made a relevant reservation under article 3(1)(a) or (b), and the claimant is of a State that is a Party that has not made a relevant reservation under article 3(1)(a)." "Where the UNCITRAL Rules on Transparency do not apply pursuant to paragraph 1, the UNCITRAL Rules on Transparency shall apply to an investor-State arbitration, whether or not initiated under the UNCITRAL Arbitration Rules, in which the respondent is a Party that has not made a reservation relevant to that investor-State arbitration under article 3(1), and the claimant agrees to the application of the UNCITRAL Rules on Transparency."
} 
future disputes. ${ }^{54}$ The MIC Statute and the accession thereto could thus already give the MIC jurisdiction to resolve investment disputes. ${ }^{55}$

One directly related question is whether joining the MIC Statute would also constitute an opt-out of ISDS options that were previously provided for in IIAs. This would depend in principle on whether only one or all the parties to the agreement of the respective IIAs join the MIC. In the event that not all parties to an IIA join the MIC Statute, the use of the MIC by investors could only be foreseen as an additional option, meaning that an opt-in would not directly result in an opt-out. If all parties to an IIA join the MIC, a corresponding amendment of the IIA could follow if this opt-out option is provided for in the MIC Statute. Possibly the MIC Statute could also foresee an optional clause allowing for Member States to opt out of dispute resolution, meaning that each individual Member of the MIC could decide whether to accept the MIC as exclusive or additional dispute resolution option for its IIAs. ${ }^{56}$

Indeed, it would be desirable to design the jurisdiction of the MIC as comprehensively as possible and to prescribe an opt-out of other ISDS as a consequence of an opt-in. The financing of the MIC among other aspects would also benefit from the above-once the MIC is established, its Members should not be sued before another forum and additional legal costs should not incur there. The possibility to specify negative admissibility requirements in the MIC statute should be considered since legal protection cannot be provided in certain cases. The members of the MIC and at the same time the parties to the IIAs in question would agree that legal protection should not necessarily exist in every case. An opt-in should therefore in practice lead to an opt-out.

\subsubsection{The Standard Case: Consensus on the Establishment of MIC Jurisdiction}

Under the MIC Statute (as an opt-in convention), the MIC should have jurisdiction over actions brought against the EU or its Member States (assuming that the EU and its Member States are parties to the MIC Statute) if the third state where the plaintiff investor comes from (and the investor bases his claim on an IIA of his home country with the EU or (one of) its Member States) is also a party to the MIC. ${ }^{57}$ In any event,

\footnotetext{
${ }^{54} \mathrm{~A}$ discussion on the possibility of use of an Opt-in Convention was also made in European Commission (2017), p. 50.

${ }^{55}$ An option similar to the Opt-in for future disputes for the MIC was proposed in Art. 30, Unified Agreement for the Investment of Arab Capital in the Arab States, 1980, through which jurisdiction of the Arab Investment Court could extend to any agreement related to an investment within the League of Arab states subject to the agreement of the parties.

${ }^{56}$ For a discussion by the Commission on the issue see European Commission (2017), p. 51.

${ }^{57}$ A similar view has been expressed in European Commission (2017), p. 50; European Union (2019), para. 35.
} 
in this case, the MIC should be added as a further dispute settlement option without any problem.

Regarding agreements already concluded in the past, dispute settlement by an MIC is obviously not foreseen, even though about $90 \%{ }^{58}$ of IIAs in force contain an ISDS mechanism. However, with the MIC Statute, jurisdiction of the MIC could be extended to existing investment protection agreements and dispute resolution systems that exist pursuant to them. ${ }^{59}$ The precondition should be that the respondent is an MIC Member and the investor comes from a state who is party to the MIC. In this case, a consensual amendment (of a bilateral treaty through a multilateral treaty) would be presumed. ${ }^{60}$

582 It must at least be discussed whether or not, due to the frequently used sunset clauses in IIAs, ${ }^{61}$ the possibility to fall back on traditional ad hoc arbitration (as has generally been provided for in IIAs up until now) can be ruled out. ${ }^{62}$ According to Article 30 para. 3 VCLT, states are allowed to modify treaties that have been concluded between them. In this respect, multilateral treaties can also amend bilateral treaties if both parties to the bilateral treaty are also parties to the multilateral treaty ${ }^{63}$ Sunset clauses should not be an obstacle. ${ }^{64}$ These are of limited use as by virtue of their wording, classification and purpose, they normally refer to the unilateral termination of agreements by one party, not to the consensual modification of the content of the treaty. ${ }^{65}$

583 As was the case in the Mauritius Convention, it should be stipulated that an establishment of MIC jurisdiction through MFN clauses is precluded. ${ }^{66}$ The absence of such provisions would lead to significant legal uncertainty, as discussions on the

\footnotetext{
${ }^{58}$ Gaukrodger and Gordon (2012), p. 10.

${ }^{59}$ This view is also supported by European Commission (2017), p. 50; European Union (2019), para. 35 .

${ }^{60} \mathrm{Cf}$. Article 39 VCLT: "A treaty may be amended by agreement between the parties. The rules laid down in Part II apply to such an agreement except in so far as the treaty may otherwise provide."

${ }^{61}$ Article 13 para. 3 German Model Treaty 2009: "In respect of investments made prior to the date of termination of this Treaty, the provisions of Articles 1 to 12 above shall continue to be effective for a further period of twenty years from the date of termination of this Treaty." See as well Article 30.9 para. 2 sentence 1 CETA: "Notwithstanding paragraph 1, in the event that this Agreement is terminated, the provisions of Chapter Eight (Investment) shall continue to be effective for a period of 20 years after the date of termination of this Agreement in respect of investments made before that date."

${ }^{62}$ Nowrot (2016), pp. 227 et seqq.; Voon et al. (2014), pp. 451 et seqq.; Binder (2016), pp. 976 et seqq.; Wackernagel (2016), pp. 11 et seqq.

${ }^{63}$ OECD (2015), p. 31.

${ }^{64}$ States have tried to work around the problem through means such as amending the treaty to delete the sunset clause and then terminating the treaty. On this, See, Busse and Lange (2018), p. 335.

${ }^{65}$ Cf. as well Kaufmann-Kohler and Potestà (2016), p. 82.

${ }^{66}$ Article 2 para. 5 Mauritius-Convention: "The Parties to this Convention agree that a claimant may not invoke a most favoured nation provision to seek to apply, or avoid the application of, the UNCITRAL Rules on Transparency under this Convention."
} 
scope of MFN clauses have been going on for a long time and ${ }^{67}$ judicial interpretation is not uniform. ${ }^{68}$

In addition, those joining the MIC should keep registers at the MIC Secretariat, which should also be published and include of every concluded treaty that shall be covered by the jurisdiction of the MIC.

\subsubsection{Exceptional Cases: Jurisdiction of the MIC Even if the Home State of the Investor Is Not an MIC Member?}

Jurisdiction could also exist simply by means of MIC membership of the respondent state, once the possibility of unilateral consent to dispute settlement is expressly foreseen in the MIC Statute (see paras. 201 et seqq.).

The inclusion of an option to bring a claim and thus establish jurisdiction in the opt-in convention in the case of non-membership of the respondent state ad hoc should be rejected in principle, but is possible.

If neither the home state of the investor, nor the host state of the investment were members of the MIC, it would also be possible to use an ad hoc agreement to establish jurisdiction. However, this is to be rejected in principle. ${ }^{69}$

If one decides to follow the above mentioned possibilities despite the concerns expressed, the MIC Statute should at least provide for the possibility of the jurisdiction of the MIC through an ad hoc compromis. Here, special rules on cost allocation should be provided for. This scenario could also lead to problems with the enforcement of decisions under the system set out in the MIC Statute; use of the proposed

\footnotetext{
${ }^{67}$ The discussion concerns on the one hand the question if an investor may claim a more favourable dispute settlement clause in a BIT of the host state with a third state or if the possibility to bring a claim in this respect does only apply to material protection standards. On the other hand, especially the EU is of the opinion that MFN clauses should generally not offer the possibility to "import" better standards from third state treaties, but need to be restricted to prohibit factual unequal treatment of third state nationals. A broad interpretation of the MFN clause would lead to investors claiming the most favourable dispute settlement clause within a BIT of the host state with a third state. See in this respect, among others, Waldermann (2015), pp. 75 et seqq.

${ }^{68}$ The possibility of investors to refer to MFN clauses, agreeing: ICSID, Case No. ARB/97/7, Maffezini v. Spain, Decision of the Tribunal on Objections to Jurisdiction of 25.1.2000, para. 64; ICSID, Case No. ARB/03/10, Gas Natural SDG, S.A. v. The Argentine Republic, Decision of the Tribunal on Preliminary Questions on Jurisdiction of. 17.6.2005, para. 31; rejecting this possibility: ICSID, Case No. ARB/03/24, Plama Consortium Limited v. Bulgaria, Decision on Jurisdiction of 8.2.2005, paras. 183 et seqq.; ICSID, Case No. ARB/02/13, Salini Costruttori S.p.A. and Italstrade S.p.A. v. The Hashemite Kingdom of Jordan, Decision on Jurisdiction of 9.11.2004, paras. 113 et seqq. In detail in this respect e.g. Stompfe (2016), pp. 273 et seqq.; Chalamish (2009), pp. 323 et seqq.; European Union (2017), para. 23.

${ }^{69} \mathrm{~A}$ discussion for use of the MIC through ad hoc procedures is seen in European Commission (2017), p. 51.
} 
fund system to settle awards in cases brought under ad hoc proceedings should be ruled out in any case.

\subsubsection{Jurisdiction of the MIC in Case of Multilateral IIAs}

589 The MIC Statute could also apply to further multilateral treaties, such as the ECT. ${ }^{70}$ If possible, it should be adopted in the future as an exclusive dispute settlement option in the field of investment protection.

590 However, this would require that all Energy Charter Member States join the MIC. These include the EU itself and most of its Member States, as well as third states. It should also be possible for individual Member States of the ECT to unilaterally recognise the jurisdiction of the MIC for proceedings based on the ECT against them.

\subsubsection{Summary of the Establishment of MIC Jurisdiction}

591 The MIC should determine that there is jurisdiction under the MIC Statute,

(a) if, in the future, i.e. following the entry into force of the MIC Statute and accession thereto, an IIA has been concluded between those MIC Members ${ }^{71}$;

(b) if an IIA has been concluded in the past between two MIC parties (consensual jurisdiction for existing treaties; a list of these treaties should also be sent to the MIC Secretariat for reasons of legal certainty; this does not mean this list should be exhaustive);

(c) if an MIC Member State has named an IIA in its list (unilateral establishment of jurisdiction for existing treaties) ${ }^{72}$; and

(d) if an IIA has not been named in the list of an MIC Member State, but is acknowledged as an ad hoc ground for jurisdiction by the respondent. ${ }^{73}$

592 For the future, it could also be considered that a ground for jurisdiction can exist

(e) if jurisdiction over an Investor State Contract is recognised in the ICS and the involved state is an MIC Member, or

(f) if jurisdiction over an ICS, although not recognised in the ICS, is subsequently recognised by a compromis and the involved state is an MIC Member.

\footnotetext{
${ }^{70}$ The European Commission has also considered the possibility of including the ECT within the ICS system, on this see, European Commission (2017), p. 27.

${ }^{71}$ As explained in paras. 247 et seqq., in such a case another ISDS-possibility might be excluded by the later amending treaty.

${ }^{72}$ As explained in paras. 579 et seqq. The MIC is in principle only one of several ISDS-possibilities.

${ }^{73}$ These alternatives could as well be covered by the before mentioned alternatives.
} 


\subsection{Transitional Provisions and System Conformity of the MIC}

As stated earlier, existing IIAs should largely remain in force, i.e. existing IIAs should be revised and modernised, and agreements of the Member States should be gradually replaced by EU agreements. The MIC would be added to the system as an alternative or new and exclusive dispute settlement option, or could replace it entirely, but it should not establish substantive protection standards.

The MIC Statute could also be seen as an amendment to the EU-Vietnam IPA and CETA (see para. 247), or as a subsequent multilateral agreement, amending bilateral agreements between certain parties to the agreement (see also to that extent Articles 30 paras. 3 and 41 VCLT). In any case, in future EU agreements, it should already be stipulated that the respective foreseen bilateral dispute settlement mechanisms cease to be in force and are replaced by MIC jurisdiction once the MIC Statute enters into force and the respective party to the agreement, in addition to the EU, has joined the MIC. ${ }^{74}$ At the same time, transitional provisions should already be made in future EU agreements in case the MIC takes over elements of its work in the future. In the case of the transfer of jurisdiction from bilateral ICS in EU agreements; the MIC Statute could also function as an amendment treaty of that EU agreement if the respective partners of the EU also become MIC Members. Corresponding detailed amendments to existing bilateral treaties could be set out in protocols and declarations to the MIC Statute.

In that regard, it could be foreseen that dispute settlement procedures that have already been initiated are completed by the respective bilateral dispute resolution system in the respective instance, but that a legal remedy would only be possible before the appellate instance of the MIC. Future EU agreements may already foresee explicit transitional provisions in the text of the agreement.

Transitional provisions are also necessary for judges that have already been appointed based on bilateral agreements-if the ICS foreseen in these agreements are replaced by the MIC. These provisions should be adopted on a case-by-case basis, depending on the agreement. In the remuneration system for CETA-ICSjudges, ${ }^{75}$ which is to be adopted by the mixed CETA Committee, it should already be stipulated that from the moment that the MIC is established or the bilateral ICS loses its jurisdiction, no new complaints can be initiated and no further retainer payments will be made.

When new members join the MIC Statute, the financing scheme must be adjusted accordingly. Representation in the Plenary Body is also immediately possible. Since accession does not involve market access obligations, as in WTO Law, but only the recognition of the MIC as (exclusive) permanent court for clearly defined types of disputes, the respective MIC accessions should be unproblematic to negotiate.

\footnotetext{
${ }^{74}$ A similar view has been expressed by the Commission in European Commission (2017), p. 58.

${ }^{75} \mathrm{Cf}$. Article 8.27 para. 12 CETA: "In order to ensure their availability, the Members of the Tribunal shall be paid a monthly retainer fee to be determined by the CETA Joint Committee."
} 
An expansion of the MIC jurisdiction to investment disputes under the ECT is currently only partially possible because it is a multilateral agreement with 53 members at this point in time. At best, a supplementary jurisdiction of the MIC could be accepted if both the respondent MIC Member as well as the host state of the complaining investor are members of the MIC (in the meaning of Article 41 para. 1 lit. b VCLT). Specific difficulties could arise here if there is an intra-EU dispute, but this is not considered at this point.

599 Mediation procedures in existing IIAs should remain untouched, i.e. mediation based on existing IIAs is still possible. ${ }^{76}$ However, it could be provided that the MIC also offers a mediation procedure, including the appointment of mediators. In this respect, a mediation center could be set up as sub-unit of the MIC which would then only have subsidiary jurisdiction in cases where no provisions on this topic exist in the bilateral IIAs.

600 The MIC could also provide in its Statute that its jurisdiction is extended to investor-state contracts, insofar as these name the MIC as a dispute settlement forum (and if the respondent state is a member of the MIC). ${ }^{77}$ This study does not assume, however, that investor-state contracts are part of the applicable law of the MIC.

601 The multilateralisation of dispute settlement mechanisms could be complemented in the future by a multilateral convention that provides for protection standards, but at the same time also emphasises the stronger and more explicit balancing of investor interests and regulatory interests of investors and states, as is already the case in recent IIAs, and foresees the MIC as a forum with jurisdiction regarding dispute settlement. Such a convention could be open to future accession of more and more members.

\subsection{Working Language and Language of Proceedings at the MIC}

602 For financial reasons, provisions on the working languages and languages of proceedings of the MIC should be established. An excessive number of working languages and languages of proceedings would considerably increase the respective procedural costs in individual cases, as translation for judges etc. would then have to be provided. Usually, English is the official and working language of most international organisations. Furthermore, the vast body of literature on public international law as well as international investment protection is written in English. Alternatively, it is possible that the MIC Statute allows the parties to the dispute to determine the language of the proceedings, in agreement with the deciding Chamber, and that the MIC Statute only specifies the working language of the Secretariat and the Plenary Body.

\footnotetext{
${ }^{76}$ The need for support for dispute avoidance mechanisms such as mediation is also seen in European Union (2019), para. 12.

${ }^{77}$ A view supporting such a proposal can be seen in European Union (2019), para. 35.
} 


\subsection{Cost Distribution in the New System}

The financing of the expected permanent costs of the MIC should be regulated, i.e. the costs of the employees of the Secretariat, the judges as well as the necessary infrastructure in form of buildings, equipment etc. From an economic perspective, the MIC only makes sense for a critical mass of Member States, if they divided the costs of such a permanent court among each other. The annual costs for the International Criminal Court are estimated at approximately EUR 130 million, ${ }^{78}$ for the WTO Secretariat with more than 600 employees at approximately CHF 198 million. $^{79}$ The CJEU and the General Court (GC), with 75 judges, 11 advocates-general and some 2170 additional employees, needs up to EUR 380 million and the ITLOS costs approximately EUR 20 million for a period of 2 years. For the MIC, an amount in the low double-digit millions should also initially be estimated. ${ }^{80}$

Although these court costs are not to be considered insignificant, the MIC will certainly be able to reduce the average cost per dispute resolution procedure. For example, costs caused by the large number of judges in bilateral investment courts, could be saved as well as those costs incurred by the international community through other arbitration fees. ${ }^{81}$ In light of the fact that average administrative costs (tribunal fees and secretary fees) are currently estimated at EUR 750,000, ${ }^{82}$ an MIC with a minimum number of members should in any case not lead to additional costs within the current system. On the contrary, if it were possible to increase efficiency through the acceleration of proceedings, this would also lead to a decrease in other costs (mostly counsel fees), which are currently estimated at approx. EUR 4 million per party involved in the dispute. ${ }^{83}$ Irrespective of the fact that a sufficient amount of states in reality would incur only limited additional costs, the MIC would not only offer a possibility to compensate for the shortcomings of the ISDS system, but also to counter balance deficits of the ICS as it is foreseen under CETA, and thus win acceptance of international jurisdiction over investment disputes.

The MIC should be financed primarily, just like other international organisations, through contributions of its members, i.e. the parties to the agreement. ${ }^{84}$ Expenditure

\footnotetext{
${ }^{78}$ Resolution on the Programme budget for 2015, the Working Capital Fund for 2015, scale of assessments for the apportionment of expenses of the International Criminal Court, financing appropriations for 2015 and the Contingency Fund, ICC-ASP/13/Res.1 of 17.12.2014; Jakobsson (2015).

${ }^{79}$ WTO, Secretariat and budget, www.wto.org/english/res_e/booksp_e/anrep_e/anrep16_chap9_e. pdf.

${ }^{80}$ The EU Commission opines that the cost for a MIC would be close to EUR 10 million per year. On this see European Commission (2017), p. 112.

${ }^{81}$ Hodgson (2014a), p. 3 assumes arbitration tribunal costs of about US $\$ 373.200$ per proceeding and party.

${ }^{82}$ Hodgson (2014b), p. 1; Hodgson (2014a), Table 2.

${ }^{83}$ Commission (2016).

${ }^{84}$ The allocation of costs among members has also been supported by the EU Commission in European Commission (2017), pp. 54 et seqq. See also Garcia-Bolivar (2015), p. 398.
} 
would determine the necessary amount which should be collected proportionally from the members. Similar to the WTO, ${ }^{85}$ the proportion that MIC Members have to bear could be calculated by taking the proportion of foreign direct investment of a state in relation to the total investment volume of all MIC Members. In order to determine the respective numbers, it is possible to make use of surveys made by the International Monetary Fund (IMF), ${ }^{86}$ World Bank ${ }^{87}$ or UNCTAD ${ }^{88}$ Proposals to impose or transfer the entire court costs to the parties to the dispute should be rejected. However, the parties should certainly be involved in financing by virtue of paying court fees, which are of course dependent on inter alia the amount involved in the dispute, as is also determined by a large number of national court cost rules. ${ }^{89}$ The members, however, should provide the basic funding.

\subsection{Overview of the Necessary Agreements and Secondary Instruments}

606 Overall, among others, the following agreements and secondary legislation appear necessary for the establishment of an MIC:

- Statute of a Multilateral Investment Court, including a Code of Conduct (MIC Statute);

- Immunity agreements between the Member States of the MIC (Agreement on Privileges and Immunities of the MIC);

- Seat agreement between the MIC, with its own legal personality, and the host state;

- Procedural rules for the first and second instance;

- Rules of procedure, including rules of conduct, for the Secretariat;

- Guidelines for the necessary contents of a statement of claim;

- Guidelines for the conduct of oral proceedings;

- Guidelines on the court costs;

- Guidelines on security deposits;

- Retirement and pension provisions for the staff of the MIC.

\footnotetext{
${ }^{85} \mathrm{Cf}$. https://www.wto.org/english/thewto_e/secre_e/contrib_e.htm.

${ }^{86}$ Cf. Coordinated Direct Investment Survey (CDIS), http://data.imf.org/?sk=40313609-F03748C1-84B1-E1F1CE54D6D5.

${ }^{87} \mathrm{Cf}$. http://data.worldbank.org/indicator/BX.KLT.DINV.WD.GD.ZS.

${ }^{88} \mathrm{Cf}$. http://unctad.org/en/Pages/DIAE/Investment\%20and\%20Enterprise/FDI_Stocks.aspx.

${ }^{89}$ Cf. e.g. Article 3 para. 1 Gerichtskostengesetz (Court Fees Act): "Die Gebühren richten sich nach dem Wert des Streitgegenstands (Streitwert), soweit nichts anderes bestimmt ist." [Unofficial English translation: "The fees are calculated according to the value of the subject matter of the dispute (value of the dispute), if not foreseen otherwise."].
} 


\section{References}

Amerasinghe CF (1996) Principles of the institutional law of international organizations. Cambridge University Press, Cambridge

American Bar Association Section on International Law (2016) Investment Treaty Working Group, Task Force Report on the Investment Court System Proposal. Initial Task Force Discussion Paper of 16.10.2016

Binder C (2016) A treaty law perspective on intra-EU BITs. J World Invest Trade 17:964-983

Boisson de Chazournes L (2012) The international tribunal for the law of the sea. In: Giorgetti C (ed) The rules, practice, and jurisprudence of international courts and tribunals. Martinus Nijhoff, Leiden, pp 111-132

Busse D, Lange S (2018) European Law and Investment Treaties. In: Legum B (ed) The Investment Treaty Arbitration Review. Law Business Research Ltd., London, pp 333-346

Chalamish E (2009) The future of bilateral investment treaties: a de facto multilateral agreement? Brooklyn J Int Law 34:303-354

Commission JP (2016) How much does an ICSID arbitration cost? A snapshot of the last five years. Kluwer Arbitration Blog of 29.2.2016

Daly W (2012) Permanent court of arbitration. In: Giorgetti C (ed) The rules, practice, and jurisprudence of international courts and tribunals. Martinus Nijhoff, Leiden, pp 37-73

European Commission (2015) Trade for all - towards a more responsible trade and investment policy, COM (2015) 497

European Commission (2016a) Establishment of a Multilateral Investment Court for investment dispute resolution, Inception Impact Assessment, Roadmap of 1.8.2016. http://ec.europa.eu/ smart-regulation/roadmaps/docs/2016_trade_024_court_on_investment_en.pdf

European Commission (2016b) Impact assessment on the establishment of a Multilateral Investment Court for investment dispute resolution. Consultation Strategy of 30.9.2016. http://trade. ec.europa.eu/doclib/docs/2016/october/tradoc_154997.pdf

European Commission (2017) Impact assessment - multilateral reform of investment dispute resolution, $\operatorname{SWD}(2017) 302$ final, 13.9.2017

European Union (2017) Possible reform of Investor-State Dispute Settlement (ISDS). Submission from the European Union, A/CN.9/WG.III/WP.145, 12 December 2017

European Union (2019) Possible reform of investor-State dispute settlement (ISDS) Submission from the European Union and its Member States, A/CN.9/WG.III/WP.159/Add.1, 24 January 2019

Garcia-Bolivar OE (2015) Permanent Investment Tribunals: the momentum is building up. In: Kalicki JE, Joubin-Bret A (eds) Reshaping the Investor-State Dispute Settlement System. Brill Nijhoff, Leiden, pp 394-402

Gaukrodger D, Gordon K (2012) Investor-State Dispute Settlement: a scoping paper for the Investment Policy Community. OECD Working Papers on International Investment 2012/03

Giorgetti C (2016) International adjudicative bodies. In: Katz Cogan J, Hurd I, Johnstone I (eds) The Oxford handbook of international organizations. Oxford University Press, Oxford, pp 881-902

Herrmann C, Weiß W, Ohler C (2007) Welthandelsrecht, 2nd edn. C.H. Beck, München

Hodgson M (2014a) Counting the costs of investment treaty arbitration. GAR News of 24.3.2014

Hodgson M (2014b) Costs in investment treaty arbitration: the case for reform. Transnl Disp Manage, 1

Jakobsson N (2015) The 2016 ICC budget - more money, more problems? Justice Hub of 17.9.2015. https://justicehub.org/article/2016-icc-budget-more-money-more-problems

Katz RL (2016) Modeling an International Investment Court after the World Trade Organization Dispute Settlement Body. Harv Negotiation Law Rev 22:163-188

Kaufmann-Kohler G, Potestà M (2016) Can the Mauritius Convention serve as a model for the reform of investor-State arbitration in connection with the introduction of a permanent investment tribunal or an appeal mechanism? 
Kunz JL (1947) Privileges and immunities of international organizations. Am J Int Law 41:828-862 Martha RSJ (2016) Exemptions from taxes, customs duties, and prohibitions on imports and exports (Article II Sections 7-8 General Convention). In: Reinisch A (ed) The conventions on the privileges and immunities of the United Nations and its specialized agencies. Oxford University Press, Oxford

Nowrot K (2016) Termination and renegotiation of international investment agreements. In: Hindelang S, Krajewski M (eds) Shifting paradigms in international investment law, pp $227-265$

OECD (2015) Developing a multilateral instrument to modify bilateral tax treaties, Action 152015 Final Report. OECD Publishing, Paris

Reinisch A (ed) (2016a) The conventions on the privileges and immunities of the United Nations and its specialized agencies. A commentary. Oxford University Press, Oxford

Reinisch A (2016b) Privileges and immunities. In: Katz Cogan J, Hurd I, Johnstone I (eds) The Oxford handbook of international organizations. Oxford University Press, Oxford, pp $1048-1068$

Ruffert M, Walter C (2015) Institutionalisiertes Völkerrecht, 2nd edn. C.H. Beck, München

Schabas WA (2010) The International Criminal Court: a commentary on the Rome Statute. Oxford University Press, Oxford

Schreuer CH, Malintoppi L, Reinisch A, Sinclair A (2009) The ICSID Convention: a commentary. Cambridge University Press, Cambridge

Stompfe P (2016) Die Gestaltung und Sicherung internationaler Investor-Staat-Verträge in der arabischen Welt am Beispiel Libyens und Katars. Nomos, Baden-Baden

UNCITRAL (2017) Possible future work in the field of dispute settlement: reforms of investor-State dispute settlement (ISDS), Note by the Secretariat of 20.4.2017. https://documents-dds-ny.un. org/doc/UNDOC/GEN/V17/023/69/PDF/V1702369.pdf?OpenElement

UNCITRAL (2018) Possible reform of investor-State dispute settlement (ISDS) Note by the Secretariat, A/CN.9/WG.III/WP.149, 5 September 2018

UNCITRAL (2019) Report on Working Group III (Investor-State-Dispute Settlement Reform) on the work of its thirty-seventh session (New York, 1-5 April 2019), A/CN.9/970

Voon T, Mitchell AD, Munro J (2014) Parting ways: the impact of mutual termination of investment treaties on investor rights. ICSID Rev 29:451-473

Wackernagel C (2016) The twilight of the BITs? EU Judicial Proceedings, the consensual termination of intra-EU BITs and why that matters for international law. Beiträge zum Transnationalen Wirtschaftsrecht Heft, p 140

Waldermann C (2015) Theorie investitionsrechtlicher Meistbegünstigung. Nomos, Baden-Baden

Open Access This chapter is licensed under the terms of the Creative Commons AttributionNonCommercial-NoDerivatives 4.0 International License (http://creativecommons.org/licenses/bync-nd/4.0/), which permits any noncommercial use, sharing, distribution and reproduction in any medium or format, as long as you give appropriate credit to the original author(s) and the source, provide a link to the Creative Commons licence and indicate if you modified the licensed material. You do not have permission under this license to share adapted material derived from this chapter or parts of it.

The images or other third party material in this chapter are included in the chapter's Creative Commons licence, unless indicated otherwise in a credit line to the material. If material is not included in the chapter's Creative Commons licence and your intended use is not permitted by statutory regulation or exceeds the permitted use, you will need to obtain permission directly from the copyright holder. 